DOI

\title{
ОСОБЛИВОСТІ АКТИВНОСТІ ТРАНСАМІНАЗ У КРОВІ ТА ПЕЧІНЦІ ПРИ ЕКСПЕРИМЕНТАЛЬНІЙ ПНЕВМОНІЇ В УМОВАХ ІММОБІЛІЗАЦІЙНОГО СТРЕСУ ТА ВПЛИВ НА НИХ КОРВІТИНУ
}

\section{Львівський національний медичний університет імені Данила Галицького}

๑Н. М. Ференц

РЕЗЮМЕ. Експериментальна пневмонія в умовах іммобілізаційного стресу супроводжується значним зростанням показників АЛТ та АСТ в крові і печінці, а застосування корвітину привело до зниження активності трансаміназ, що свідчить про його позитивний корегувальний вплив на ці показники.

КЛЮчОВІ СЛОВА: експериментальна пневмонія, стрес, аланінамінотрансфераза, аспартатамінотрансфераза, корвітин.

Вступ. Пневмонія займає велику питому вагу в структурі захворюваності органів дихання. Ця хвороба у двадцять першому столітті залишається важливою медико-соціальною проблемою, тому що призводить до значних економічних збитків, спричиняє періоди непрацездатності. На сьогодні у практичній роботі лікаря часто зустрічаються як гіпо- так і гіпердіагностика пневмонії. Як відомо, несвоєчасна і хибна діагностика та неправильне лікування призводять до розвитку тяжких ускладнень.

За останні тридцять років летальність від пневмонії зросла від 1 до $9 \%$ і найчастіше спостерігається в осіб старших 55 років $[1,2]$.

Етіологічні чинники цього захворювання на сьогодні уже відомі, проте залишається неповністю з'ясованим механізм розвитку пневмонії [2], невивчені питання, які стосуються змін активності трансаміназ у крові в динаміці формування експериментальної пневмонії в умовах іммобілізаційного стресу та вплив на них антиоксиданта корвітину.

Метою нашого дослідження було з'ясувати особливості змін активності трансаміназ у крові і печінці при експериментальній пневмонії в умовах іммобілізаційного стресу та встановити коригувальну дію на них корвітину.

Матеріал і методи дослідження. Дослідження проводили на 40 морських свинках (самцях) масою тіла 180-220 г, які були поділені на 4 групи: перша група - контрольні (інтактні) тварини (10); друга група - тварини з ЕП (10) до лікування; третя група - тварини з ЕП та IC (10) до лікування; четверта група - тварини з ЕП та IC (10) після лікування корвітином, який вводили внутрішньом'язово у дозі 40 мг/кг маси впродовж 10 днів.

Експериментальну модель пневмонії відтворювали шляхом інтраназального зараження тварин культурою Staphylococcus aureus за методом В. Н. Шляпникова, Т. Л. Солодова, С. А. Степанова (1988) $[4,5]$. Іммобілізаційний стрес моделювали за методом П. Д. Горизонтова, О. И. Белоусова
(1983) шляхом нетравматичної фіксації тварин на спині впродовж 3 годин [3].

Потім тварин декапітували і визначали у крові та печінці вміст показників трансаміназ на 1, 3, 6 і 10 доби розвитку ЕП та IC до та після лікування корвітином на 10 добу експерименту. Вміст аланінамінотрансферази (АЛТ) і аспартатамінотрансферази (АСТ) визначали за методом S. Reitman, S. Frankel [6].

Опрацювання цифрових даних проводили методом варіаційної статистики з використанням критерію Стьюдента.

Результати й обговорення. Результати біохімічних досліджень показали, що на 1 добу формування ЕП і ІМ спостерігалось підвищення активності АСТ в печінці на $31,0 \%(P<0,05)$ і АЛТ на 33,0 \% $(P<0,05)$ відносно контролю. Пізніше, на 3 добу експерименту, було виявлено подальше зростання активності АСТ на 44,0\% $(P<0,05)$ і АЛТ В печінці на $38,5 \%(P<0,05)$ проти інтактної групи морських свинок.

Нами встановлено, що на 6 добу при ЕП в умовах IC відбувалося підвищення активності АСТ у печінці на 50,0\% $(P<0,05)$ і АЛТ на 37,0\% $(P<0,05)$, i В найпізніший термін спостереження (10 доба) також виявлено зростання цих ферментів відповідно на $65,0 \%(P<0,05)$ і 46,0 \% $(P<0,05)$, порівняно 3 першою групою тварин (рис. 1).

Проведені дослідження показали, що на 1 і 3 доби формування експериментальної пневмонії та іммобілізаційного стресу відбулося підвищення активності АСТ у крові відповідно на 83,7 \% $(P<0,05)$ і $96,8 \%(P<0,05)$ та АЛТ на $56,0 \%(P<0,05)$ і 70,7 \% ( $><0,05)$ відносно контролю. Згодом, на 6 і 10 доби запального процесу в легенях та розвитку іммобілізаційного стресу було встановлено подальше зростання активності АСТ у крові відповідно на 94,6\% $(P<0,05)$ і 145,6\% $(P<0,05)$ та АлТ на $78,0 \%(P<0,05)$ і $107,3 \%(P<0,05)$ проти інтактної групи тварин, що свідчило про пошкодження клітин та вихід з них у кров трансаміназ (рис. 2). 


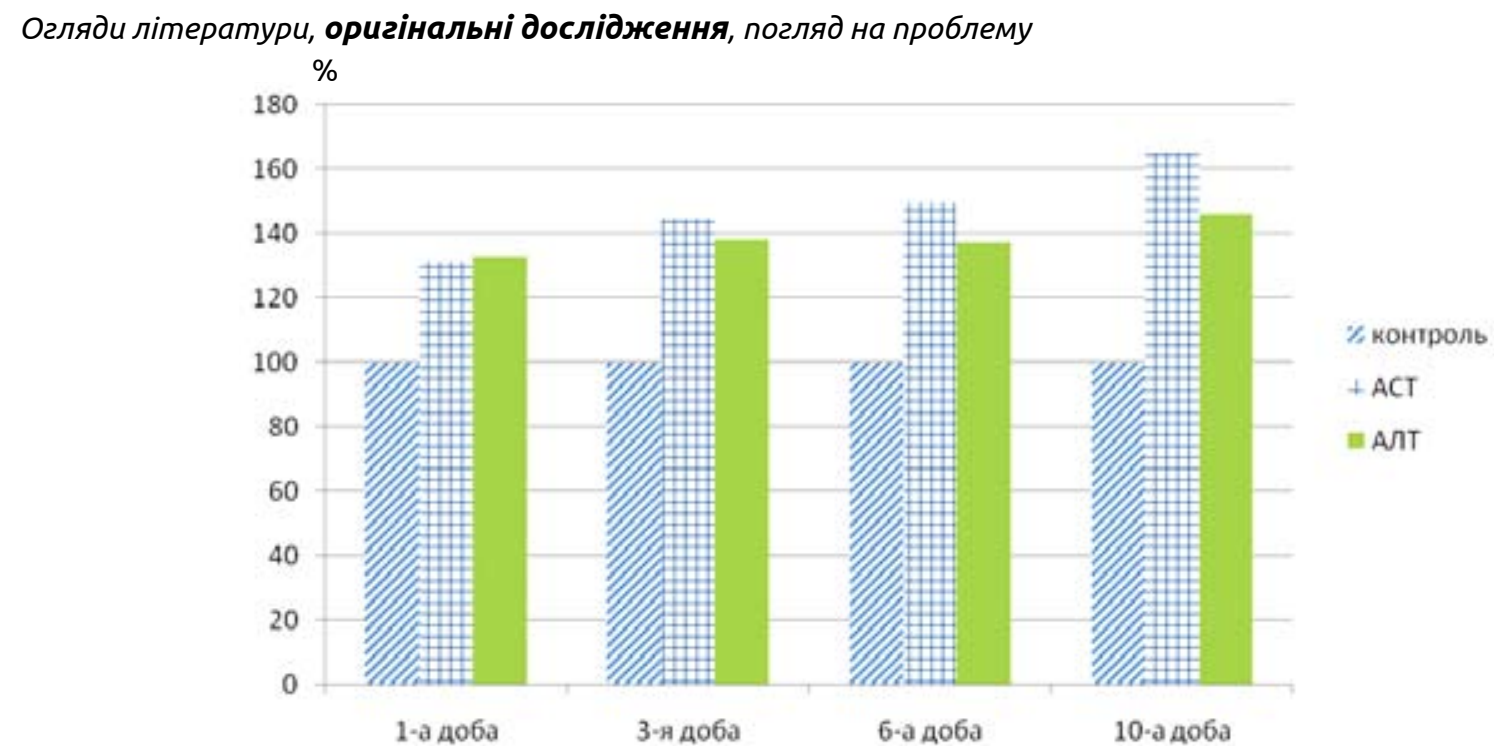

Рис. 1. Активність трансфераз у печінці тварин при ЕП в умовах іммобілізаційного стресу (у \% від контролю).

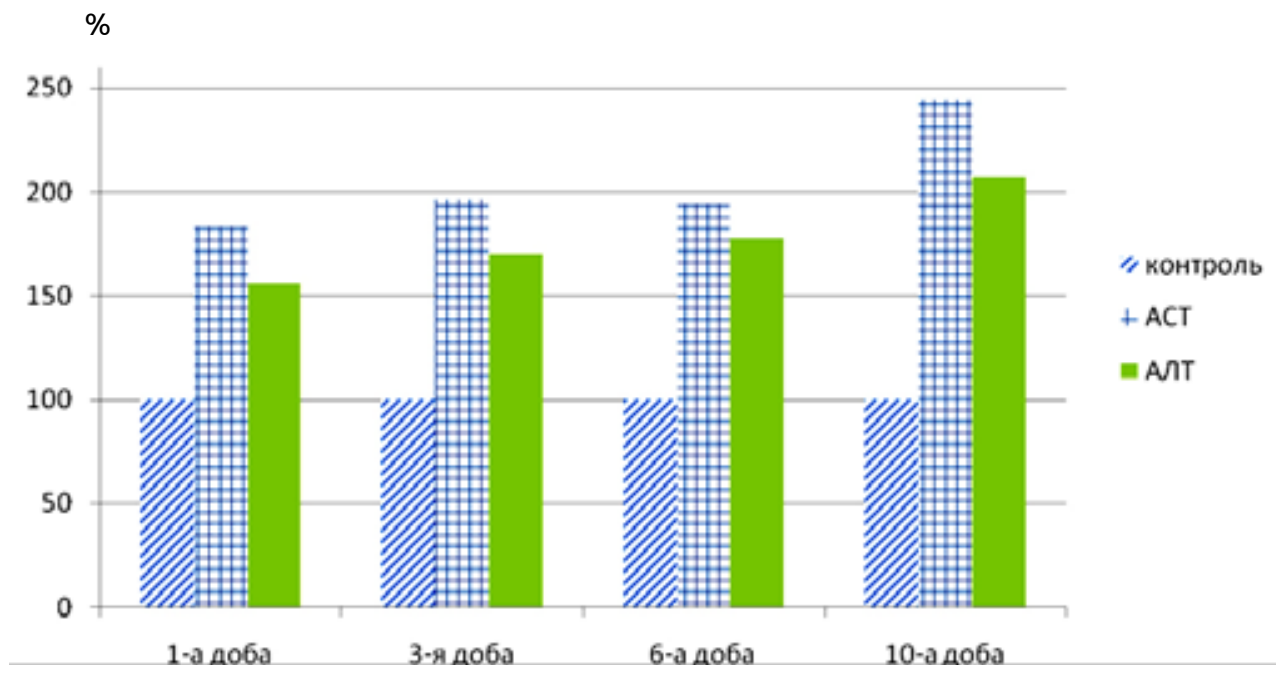

Рис. 2. Активність трансфераз у крові тварин при ЕП в умовах іммобілізаційного стресу (у \% від контролю)

Проведене біохімічне дослідження АСТ і АЛТ показало зростання їх активності як у печінці, так і в крові, за умов поєднаного впливу запального процесу в легенях та іммобілізаційного стресу впродовж усього періоду експерименту, що свідчило про пошкодження гепатоцитів та вихід із них у кров зазначених ферментів.

Порівнявши аналіз результатів дослідження тварин з експериментальною пневмонією в умовах іммобілізаційного стресу після застосування препарату корвітину ми отримали зниження рівня показників у крові АЛТ на $30,5 \%(P<0,05)$ та АСТ у крові на 46,3 \% (Р<0,05), в печінці відбулись аналогічні зміни: АЛТ і АСТ на $27 \%(P<0,05)$ та $17,4 \%(P<0,05)$ відповідно (рис. 3). Це дозволяє зробити висновок, що цей антиоксидант і гепатопротектор чинить позитивну дію на вказані показники.
Висновки і перспективи подальших досліджень. Проведені експериментальні дослідження вказують на зміни метаболічних процесів в клітинах печінки, ушкодження плазматичної мембрани й порушення функції гепатоцитів при експериментальній пневмонії в умовах іммобілізаційного стресу, що проявляються зростанням показників АЛт та АСТ в крові і в печінці і можуть бути використані в подальшій науково-дослідній роботі та в навчальному процесі, а застосування препарату корвітину привело до зниження активності трансаміназ, що свідчить про його позитивний корегуючий вплив на ці показники та вказує на доцільність і перспективність його подальшого вивчення в експерименті та в клініці з метою корекції виявлених метаболічних порушень при пневмонії в умовах стресу та розробки методичних рекомендацій. 
Огляди літератури, оригінальні дослідження, погляд на проблему

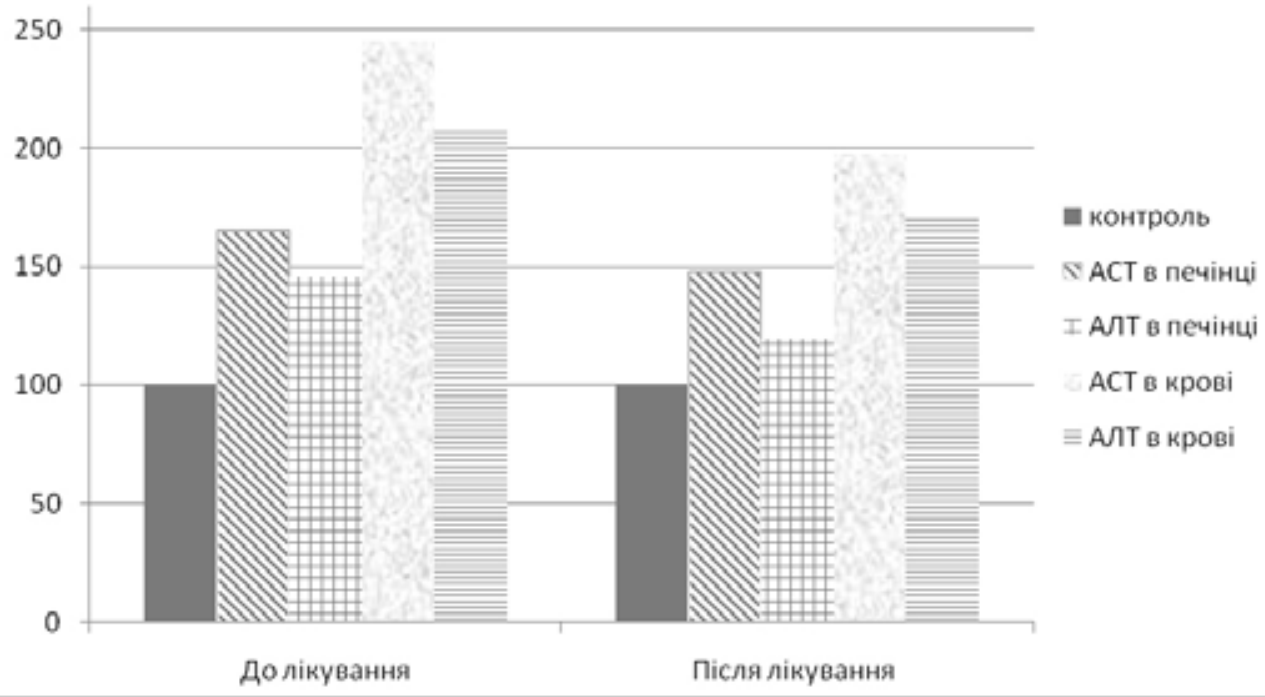

Рис. 3. Вплив корвітину на активність трансаміназ у печінці і крові при ЕП в умовах іммобілізаційного стресу (у \% при порівнянні до та після лікування корвітином на 10 добу експерименту).

\section{ЛІТЕРАТУРА}

1. Регеда М. С. Пневмонія / М. С. Регеда. - 3-є перевидання. - Львів. : Сполом, 2005. - 138 с.

2. Регеда М. С. Запальні хвороби легень та бронхів : монографія / М. С. Регеда. - Львів, 2008. - 206 с.

3. Горизонтов П. Д. Стресс и система крови /П. Д. Горизонтов, О. И. Белоусова, М. И. Федотов. - М. : Медицина, 1983. - 338с.

4. Экспериментальные модели острых пневмоний, вызванных условно-патогенными бактериями и их ассоциациями: метод. рекомендации / В. Н. Шляп- ников, Т. Л. Солодова, С. А. Степанов [и др.]. - Саратов : Саратовский медицинский институт, 1988. - 30 с.

4. The experimental model of acute pneumonia caused by conditionally - pathogenic bacteria and their associations / V. N. Schlyapnikov, T. L. Solodova, S. A. Stepanov [et al.]. - Saratov: Saratov Medical Institute, 1988. - 30 p.

5. Reitman S. Colorimetric method for the determination of glutamic oxaloacetic and glutamic pyruvic transaminases / S. Reitman, S. Frankel // Am. J. Clin. Pathol. -1957.№ 28. - P. 56.

\section{FEATURES OF TRANSAMINASE ACTIVITY IN BLOOD AND LIVER IN EXPERIMENTAL PNEUMONIA UNDER IMMOBILIZATION STRESS AND INFLUENCE OF CORVITIN ON THEM}

ON. M. Ferents

\section{Lviv National Medical University by Danylo Galytskyi}

SUMMARY. Experimental pneumonia in the conditions of immobilization stress is accompanied by a significant increase in ALT and AST indicators in the blood and liver, and the drug Corvitin led to a decrease in transaminase activity, indicating that the adjustment of its positive impact on these indexes.

KEY WORDS: experimental pneumonia, stress, alaninaminotransferase, aspartataminotransferase, corvitin.

Отримано 15.03.2016 